\title{
Article \\ Identifying Potential Antioxidant Properties from the Viscera of Sea Snails (Turbo cornutus)
}

\author{
Nalae Kang ${ }^{1}$, Eun-A Kim ${ }^{1}$, Junseong Kim ${ }^{1}$, Seung-Hong Lee ${ }^{2, *}$ and Soo-Jin Heo ${ }^{1,3, *}$ \\ 1 Jeju Marine Research Center, Korea Institute of Ocean Science and Technology (KIOST), Jeju 63349, Korea; \\ nalae1207@kiost.ac.kr (N.K.); euna0718@kiost.ac.kr (E.-A.K.); junseong@kiost.ac.kr (J.K.) \\ 2 Department of Pharmaceutical Engineering and Medical Science, Soonchunhyang University, \\ Asan 31538, Korea \\ 3 Department of Biology, University of Science and Technology (UST), Daejeon 34113, Korea \\ * Correspondence: seunghong0815@gmail.com (S.-H.L.); sjheo@kiost.ac.kr (S.-J.H.)
}

check for updates

Citation: Kang, N.; Kim, E.-A.; Kim, J.; Lee, S.-H.; Heo, S.-J. Identifying Potential Antioxidant Properties from the Viscera of Sea Snails (Turbo cornutus). Mar. Drugs 2021, 19, 567. https://doi.org/10.3390/md19100567

Academic Editors: Hideki Kishimura and Yuya Kumagai

Received: 30 July 2021

Accepted: 7 October 2021

Published: 13 October 2021

Publisher's Note: MDPI stays neutral with regard to jurisdictional claims in published maps and institutional affiliations.

Copyright: (C) 2021 by the authors Licensee MDPI, Basel, Switzerland. This article is an open access article distributed under the terms and conditions of the Creative Commons Attribution (CC BY) license (https:// creativecommons.org/licenses/by/ $4.0 /)$.
Abstract: Turbo cornutus, the horned turban sea snail, is found along the intertidal and basaltic shorelines of Jeju Island, Korea. T. cornutus feeds on seaweeds (e.g., Undaria sp., and Ecklonia sp.) composed of diverse antioxidants. This study identified potential antioxidant properties from T. cornutus viscera tissues. Diverse extracts were evaluated for their hydrogen peroxide $\left(\mathrm{H}_{2} \mathrm{O}_{2}\right)$ scavenging activities. T. cornutus viscera protamex-assisted extracts (TVP) were purified by gel filtration chromatography (GFC), and potential antioxidant properties were analyzed for their amino acid sequences and its peroxidase inhibition effects by in silico molecular docking and in vitro analysis. According to the results, T. cornutus viscera tissues are composed of many protein contents with each over $50 \%$. Among the extracts, TVP possessed the highest $\mathrm{H}_{2} \mathrm{O}_{2}$ scavenging activity. In addition, TVP-GFC-3 significantly decreased intracellular reactive oxygen species (ROS) levels and increased cell viability in $\mathrm{H}_{2} \mathrm{O}_{2}$-treated HepG2 cells without cytotoxicity. TVP-GFC-3 comprises nine low molecular bioactive peptides (ELR, VGPQ, TDY, ALPHA, PAH, VDY, WSDK, VFSP, and FAPQY). Notably, the peptides dock to the active site of the myeloperoxidase (MPO), especially TDY and FAPQY showed the MPO inhibition effects with $\mathrm{IC}_{50}$ values of $646.0 \pm 45.0 \mu \mathrm{M}$ and $57.1 \pm 17.7 \mu \mathrm{M}$, respectively. Altogether, our findings demonstrated that T. cornutus viscera have potential antioxidant properties that can be used as high value-added ingredients.

Keywords: Turbo cornutus; viscera; antioxidant; hydrogen peroxide; bioactive peptide

\section{Introduction}

Turbo cornutus, an edible gastropod species with a horned turban, is found along the intertidal and basaltic shorelines of Jeju Island, Korea. T. cornutus is a major source of income for Jeju Haenyeo (women divers; Intangible Cultural Heritage, 2016). The muscle tissues of T. cornutus are used as local foods in Jeju, Korea, but most of its viscera tissues are discarded because of low consumer preference and awareness. Some studies published in the 1970s-2000s presented the physioecology of T. cornutus [1-3]. T. cornutus is an herbivorous marine animal that feeds on seaweeds composed of diverse antioxidants [4]. However, the nutritional and functional ingredients of T. cornutus remain unknown.

Under normal physiological conditions, intracellular reactive oxygen species (ROS) are maintained at a constant low level by the balance between the generation and elimination of ROS [5]. However, ROS generated without control can induce oxidative damage to intracellular biomacromolecules, such as protein, membrane lipid, RNA, and DNA [5,6]. Hydrogen peroxide $\left(\mathrm{H}_{2} \mathrm{O}_{2}\right)$ is a ROS that, when present in excess, can be harmful to cells [7]. In addition, $\mathrm{H}_{2} \mathrm{O}_{2}$ can be converted the hypohalous acids, causing oxidative damage by the Myeloperoxidase (MPO) $/ \mathrm{H}_{2} \mathrm{O}_{2}$ system [8,9]. Thus, the removing $\mathrm{H}_{2} \mathrm{O}_{2}$ is very important to combat oxidative stress and MPO-dependent ROS [10,11]. 
Several antioxidants prevent and relieve oxidative damage caused by ROS [12]. Exogenous antioxidants are widely distributed in food and medicinal plants and food processing by-products, such as seafood viscera [13-16]. From this, many studies are being conducted on search for natural antioxidant compounds.

Yearly, a considerable amount of world fishery resources are discarded as processing leftovers, such as viscera, gonads, bones, and skin [17]. These marine by-products cause problems, such as environmental pollution. Thus, efforts to explore the possibilities for the further use of marine by-products have become more important than the methods of their disposal [18-21]. Recently, much research is conducted to explore the possible uses of different by-products; many studies have presented that marine by-products contain valuable protein fractions, including surimi [22], gelatin/collagen [23], and bioactive peptides [24]. Producing functional food materials and other value-added products from marine by-products is a way to obtain attention because marine by-products contain valuable protein and lipid fractions, pigments, minerals, enzymes, and nutraceuticals or pharmacological $[18,20]$.

The objective of this study is to explore valuable application process that can reuse the discarded viscera of $T$. conutus. The potential antioxidant properties were purified from T. cornutus viscera through enzymatic hydrolysis and gel filtration chromatography (GFC); also, its antioxidant activities were assessed in $\mathrm{H}_{2} \mathrm{O}_{2}$-treated HepG2 cells. Furthermore, the bioactive peptides that composed the potential antioxidant properties were analyzed for their peroxidase inhibition effect.

\section{Results and Discussion}

\subsection{Proximate Composition of T. cornutus}

The proximate composition of each T. cornutus viscera and muscle is shown in Table 1. Protein was the major chemical component of the T. cornutus viscera; protein contents accounted for $52.68 \% \pm 0.28 \%$ of the total dry weight. The lipid, moisture, ash, and carbohydrate contents of T. cornutus viscera were $28.40 \% \pm 1.20 \%, 1.03 \% \pm 0.35 \%, 14.79 \% \pm 0.80 \%$, and $3.12 \% \pm 1.93 \%$, respectively. The major chemical component of the T. cornutus muscle was protein; protein contents accounted for $78.28 \% \pm 2.23 \%$ of the total dry weight. The lipid, moisture, ash, and carbohydrate contents of T. cornutus muscle were $10.90 \% \pm 0.81 \%$, $4.25 \% \pm 3.66 \%, 4.86 \% \pm 0.40 \%$, and $1.73 \% \pm 1.85 \%$, respectively. Thus, T. cornutus viscera and muscle are rich protein sources.

Table 1. The proximate composition of T. cornutus (\% on dry weight).

\begin{tabular}{ccc}
\hline & Viscera & Muscle \\
\hline Proteins & $52.68 \pm 0.28$ & $78.28 \pm 2.23$ \\
Lipids & $28.40 \pm 1.20$ & $10.90 \pm 0.81$ \\
Moisture & $1.03 \pm 0.35$ & $4.25 \pm 3.66$ \\
Ash & $14.79 \pm 0.80$ & $4.86 \pm 0.40$ \\
Carbohydrates & $3.12 \pm 1.93$ & $1.73 \pm 1.85$ \\
Total & 100 & 100 \\
\hline
\end{tabular}

\subsection{Amino Acid Composition of T. cornutus}

The amino acid compositions of T. cornutus viscera and muscle are listed in Table 2. The most abundant amino acids in the T. cornutus viscera are aspartic acid $(10.3 \pm 0.0 \%)$, glutamic acid $(13.1 \pm 0.2 \%)$, and taurine $(11.3 \pm 0.1 \%)$, each of which comprises more than $10 \%$ of the T. cornutus viscera, followed by arginine $(7.1 \pm 0.5 \%)$, leucine $(6.5 \pm 0.1 \%)$, and proline $(6.2 \pm 0.3 \%)$. Alternatively, the most abundant amino acids in the T. cornutus muscle are aspartic acid $(9.5 \pm 0.2 \%)$, glutamic acid $(16.4 \pm 0.1 \%)$, and arginine $(9.6 \pm 0.0 \%)$, followed by glycine $(8.8 \pm 0.2 \%)$, taurine $(8.1 \pm 0.0 \%)$, and leucine $(6.3 \pm 0.1 \%)$. Aspartic acid, glutamic acid, arginine, and glycine are the most abundant amino acids in other marine animals, such as abalone [25]. Both the viscera and muscle contain the most abundant aspartic and glutamic acid. The viscera and muscle contain about $30 \%$ of the essential amino acid composition, such as histidine, threonine, valine methionine, phenylalanine, isoleucine, leucine, and lysine, for humans. Therefore, both of them are high-quality protein sources. 
Table 2. The amino acids composition of T. cornutus (\% of total amino acids).

\begin{tabular}{ccc}
\hline & Viscera & Muscle \\
\hline Aspartic acid & $10.3 \pm 0.0$ & $9.5 \pm 0.2$ \\
Glutamic acid & $13.1 \pm 0.2$ & $16.4 \pm 0.1$ \\
Serine & $4.9 \pm 0.1$ & $4.7 \pm 0.1$ \\
Histidine & $1.8 \pm 0.0$ & $1.1 \pm 0.1$ \\
Glycine & $5.5 \pm 0.4$ & $8.8 \pm 0.2$ \\
Threonine & $5.2 \pm 0.1$ & $4.4 \pm 0.0$ \\
Arginine & $7.1 \pm 0.5$ & $9.6 \pm 0.0$ \\
Alanine & $5.0 \pm 0.1$ & $5.9 \pm 0.0$ \\
Taurine & $11.3 \pm 0.1$ & $8.1 \pm 0.0$ \\
Tyrosine & $3.5 \pm 0.0$ & $2.6 \pm 0.0$ \\
Valine & $4.4 \pm 0.3$ & $3.3 \pm 0.2$ \\
Methionine & $2.3 \pm 0.1$ & $2.2 \pm 0.2$ \\
Phenylalanine & $4.4 \pm 0.1$ & $2.8 \pm 0.1$ \\
Isoleucine & $3.8 \pm 0.3$ & $3.1 \pm 0.2$ \\
Leucine & $6.5 \pm 0.1$ & $6.3 \pm 0.1$ \\
Lysine & $4.8 \pm 0.1$ & $4.5 \pm 0.9$ \\
Proline & $6.2 \pm 0.3$ & $6.6 \pm 1.9$ \\
Total & 100 & 100 \\
\hline
\end{tabular}

\section{3. $\mathrm{H}_{2} \mathrm{O}_{2}$ Scavenging Activity of the Enzymatic Extracts of T. cornutus}

To assess the $\mathrm{H}_{2} \mathrm{O}_{2}$ scavenging activity of $T$. cornutus viscera and muscle, each viscera and muscle tissues was hydrolyzed with nine proteases: alcalase, flavourzyme, neutrase, protamex, pepsin, trypsin, $\alpha$-chymotrypsin, bromelain, and papain. The extraction yields of diverse T. cornutus enzyme-assisted extracts are summarized in Figure 1A. The T. cornutus viscera enzyme-assisted extracts showed more than $40 \%$ extraction yields, with $T$. cornutus viscera protamex-assisted extracts (TVP) having the highest extraction yield (70\%). In contrast, the T. cornutus muscle enzyme-assisted extracts showed higher extraction yields than those of the viscera.

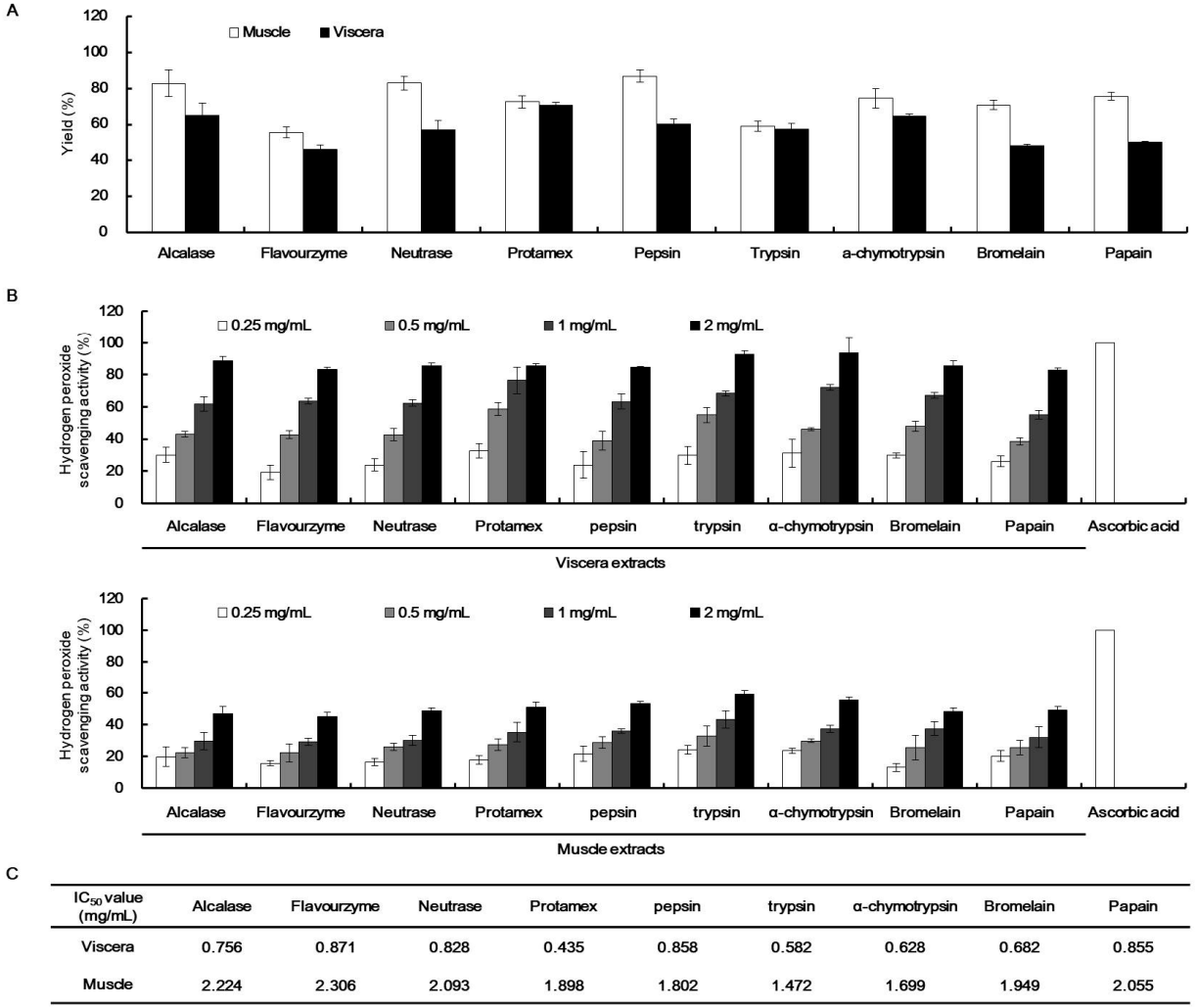

Figure 1. Extraction yields and hydrogen peroxide $\left(\mathrm{H}_{2} \mathrm{O}_{2}\right)$ scavenging activities of Turbo cornutus extracts. The extraction yields (A), $\mathrm{H}_{2} \mathrm{O}_{2}$ scavenging activities (B), and $\mathrm{IC}_{50}$ values (C) of each T. cornutus viscera and muscle enzyme-assisted extract. (C) $\mathrm{IC}_{50}$ values on $\mathrm{H}_{2} \mathrm{O}_{2}$ scavenging activities of Turbo cornutus extracts. 
The $\mathrm{H}_{2} \mathrm{O}_{2}$ scavenging activities of the enzymatic extracts of $T$. cornutus viscera and muscle were shown in Figure $1 \mathrm{~B}, \mathrm{C}$. The viscera extracts indicated higher $\mathrm{H}_{2} \mathrm{O}_{2}$ scavenging activities than those of the muscle extracts in a concentration ranging from 0.25 to $2 \mathrm{mg} / \mathrm{mL}$. The viscera extracts showed more than $80 \% \mathrm{H}_{2} \mathrm{O}_{2}$ scavenging activities at $2 \mathrm{mg} / \mathrm{mL}$. In addition, the viscera extracts showed approximately three times higher $\mathrm{IC}_{50}$ values of $\mathrm{H}_{2} \mathrm{O}_{2}$ scavenging activities against each muscle extract, with TVP having the lowest $\mathrm{IC}_{50}$ value of $0.435 \mathrm{mg} / \mathrm{mL}$.

\subsection{Effect of Viscera and Muscle Extracts on $\mathrm{H}_{2} \mathrm{O}_{2}$-Induced Oxidative Stress in HepG2 Cells}

The liver is a vital organ that plays a major role in metabolism, excretion, and detoxification in the human body. Liver impairment is caused by different factors, such as infection, drugs, and excessive ethanol intake, leading to the accumulation of ROS and various liver injuries by oxidative stress. Thus, oxidative stress prevention is needed for hepatoprotection [26]. ROS are broadly defined as chemically reactive molecules containing oxygen; these include hydroxyl radical $\left(\mathrm{OH} \cdot{ }^{\circ}\right)$, superoxide anion $\left(\mathrm{O}_{2}{ }^{-}\right)$, singlet oxygen $\left(\mathrm{O}_{2}\right)$, and $\mathrm{H}_{2} \mathrm{O}_{2}\left(\mathrm{H}_{2} \mathrm{O}_{2}\right)$ [5]. ROS react with molecules by reversible oxidative modifications and factors in cellular signaling pathways, such as metabolism, growth, differentiation, and death signaling [5]. However, ROS overproduction without control can result in oxidative damage to cell structures, including lipids and membranes, proteins, and DNA $[5,26]$. Therefore, the MTT assay was performed in $\mathrm{H}_{2} \mathrm{O}_{2}$-exposed HepG2 cells to evaluate the potential antioxidant effect of viscera and muscle extract s. As shown in Figure 2, significant cell death was observed in the $\mathrm{H}_{2} \mathrm{O}_{2}$-treated cells. However, TVP and the muscle protamex extract markedly increased cell viability. Especially, TVP showed a higher protective effect than did muscle protamex-assisted extracts against $\mathrm{H}_{2} \mathrm{O}_{2}$ in HepG2 cells. In addition, TVP inhibited intracellular ROS production, and aspartate aminotransferase (AST) levels increased by treating $\mathrm{H}_{2} \mathrm{O}_{2}$ in HepG2 cells. These results indicated that T. cornutus viscera tissues possess a high value than did T. cornutus muscle tissues by protamex-assisted hydrolysis processing.

A
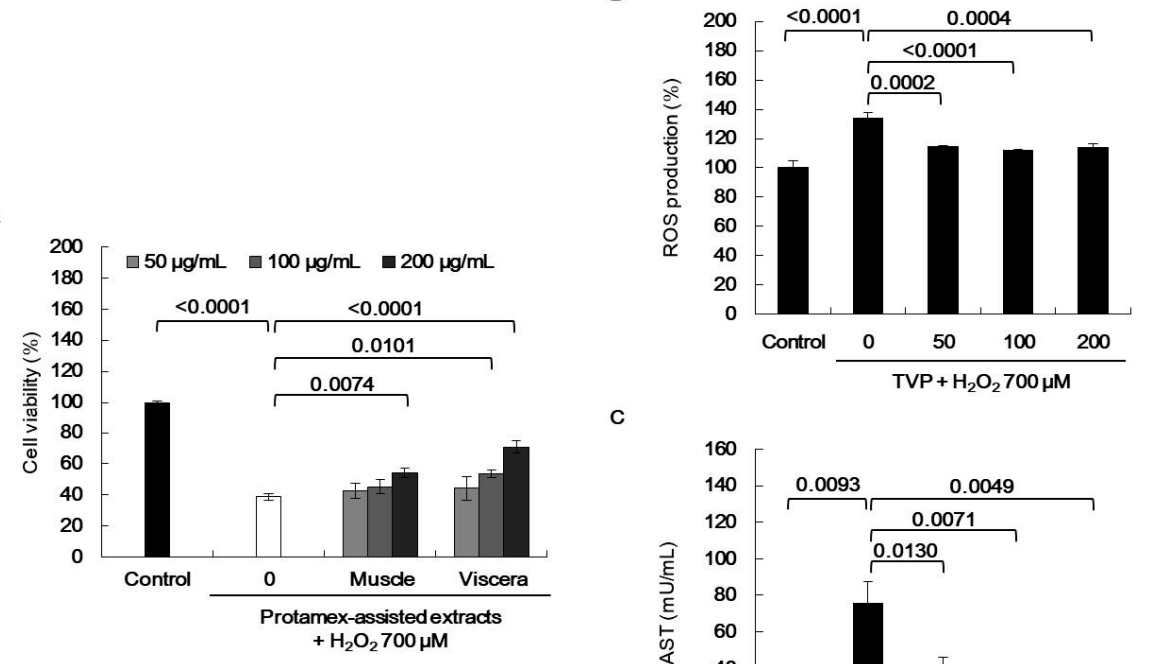

c

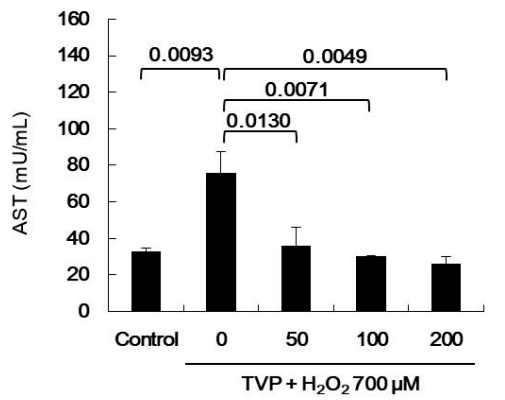

Figure 2. Effects of Turbo cornutus extracts on hydrogen peroxide $\left(\mathrm{H}_{2} \mathrm{O}_{2}\right)$-induced oxidative stress in HepG2 cells. (A) Protective effect of each T. cornutus muscle and viscera protamex extracts on oxidative stress in HepG2 cells. (B) Intracellular reactive oxygen species production inhibition effects of T. cornutus viscera protamex extracts (TVP) on oxidative stress in HepG2 cells. (C) Aspartate aminotransferase (AST) production inhibition effects of TVP on oxidative stress in HepG2 cells. The data are expressed as means \pm standard deviation (SD) of three determinations. 


\subsection{Characterization of Antioxidant Peptides from TVP}

Depending on the $\mathrm{H}_{2} \mathrm{O}_{2}$ scavenging activity and protective effect on $\mathrm{H}_{2} \mathrm{O}_{2}$ in HepG2 cells, TVP was selected for the next separation step by GFC on Sephadex G-25 column. TVP was fractionated to four kinds of fractions according to their molecular sizes (Figure 3A). Among them, GFC-Fr.3 (TVP-GFC-3) had the highest $\mathrm{H}_{2} \mathrm{O}_{2}$ scavenging activity at a concentration of $0.25 \mathrm{mg} / \mathrm{mL}$ (Figure 3B,C). TVP-GFC-3 significantly increased $\mathrm{IC}_{50}$ values than did TVP. In addition, TVP-GFC-3 significantly decreased ROS generation and increased protective effects in $\mathrm{H}_{2} \mathrm{O}_{2}$-exposed $\mathrm{HepG} 2$ cells without cytotoxicity (Figure 4). To identify the amino acid sequences of the separated fraction, TVP-GFC-3 was analyzed using MicroQ-time-of-flight (TOF) tandem mass spectrometry. TVP-GFC-3 comprises nine small molecule peptides, and the amino acid sequences of the peptides were evaluated as ELR, VGPQ, TDY, ALPHA, PAH, VDY, WSDK, VFSP, and FAPQY (Table 3, Figures S1-S10).

Table 3. Nine bioactive peptides from TVP-GFC-3.

\begin{tabular}{cccc}
\hline Sample & Charge & $\mathbf{m} / \mathbf{z}$ & Sequencing \\
\hline TVP-GFC-3 & 1 & 417.25 & ELR \\
& 1 & 400.22 & VGPQ \\
1 & 398.16 & TDY \\
1 & 508.29 & ALPAH \\
& 1 & 324.17 & PAH \\
1 & 396.18 & VDY \\
1 & 535.25 & WSDK \\
& 1 & 449.24 & VFSP \\
& 1 & 625.30 & FAPQY \\
\hline
\end{tabular}

A

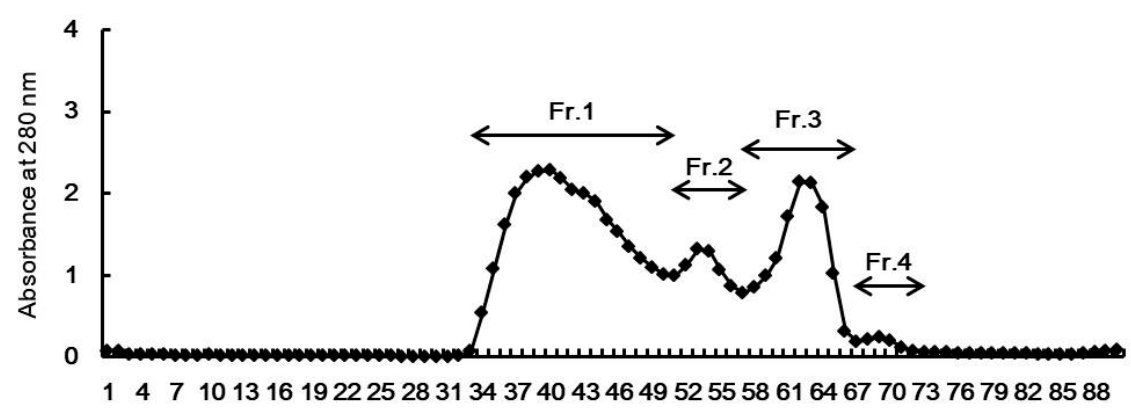

B

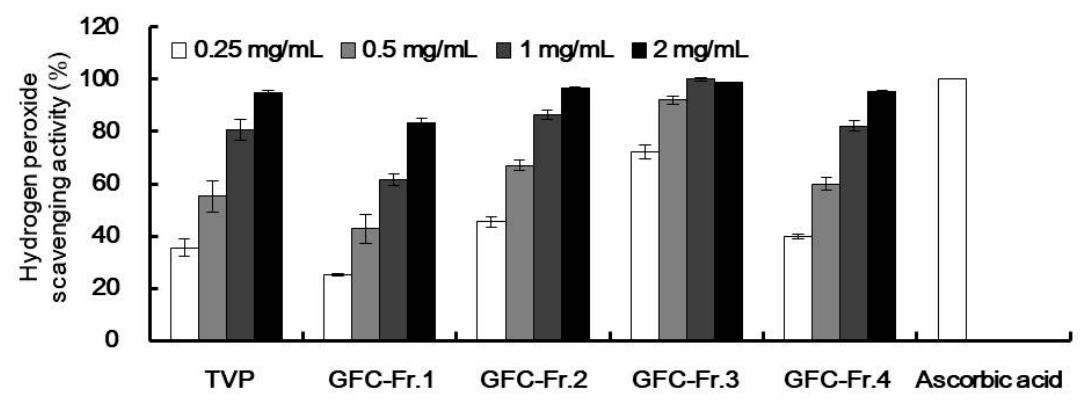

C

\begin{tabular}{ccccccc}
\hline & TVP & GFC-Fr.1 & GFC-Fr.2 & GFC-Fr.3 & GFC-Fr.4 & Ascorbic acid \\
\hline $\begin{array}{c}\mathrm{IC}_{50} \text { value } \\
(\mathrm{mg} / \mathrm{mL})\end{array}$ & 0.463 & 0.729 & 0.271 & $<0.250$ & 0.390 & - \\
\hline
\end{tabular}

Figure 3. Hydrogen peroxide $\left(\mathrm{H}_{2} \mathrm{O}_{2}\right)$ scavenging activities of Turbo cornutus viscera protamex extract gel filtration chromatography fractions. (A) Gel filtration chromatogram of T. cornutus viscera protamex extracts using Sephadex G-25. $\mathrm{H}_{2} \mathrm{O}_{2}$ scavenging activities (B) and $\mathrm{IC}_{50}$ values (C) of each fraction. 
A

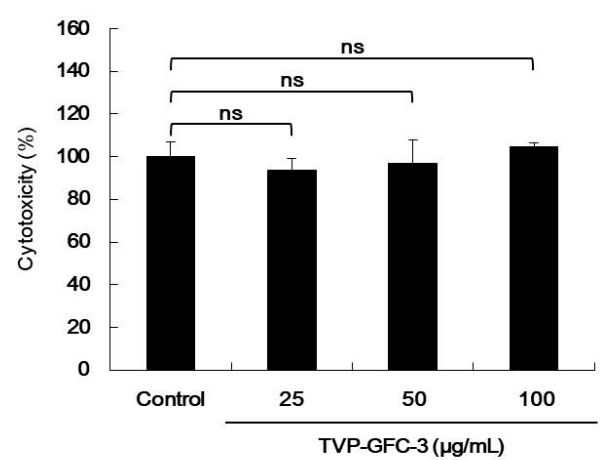

B

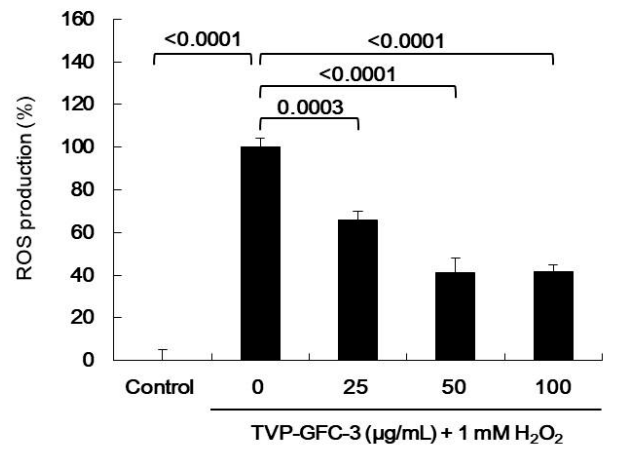

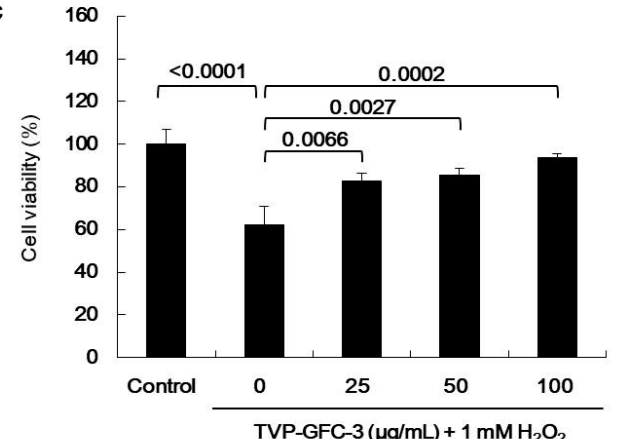

Figure 4. Effects of Turbo cornutus viscera protamex extract gel filtration chromatography (GFC) fractions on $\mathrm{H}_{2} \mathrm{O}_{2}$-induced oxidative stress in HepG2 cells. (A) Cytotoxicity of T. cornutus viscera protamex extract GFC fraction 3. (B) Intracellular reactive oxygen species production inhibition effects of T. cornutus viscera protamex extract GFC fraction 3 on oxidative stress in HepG2 cells. (C) AST production inhibition effects of T. cornutus viscera protamex extract GFC fraction 3 on oxidative stress in HepG2 cells. The data are expressed as means \pm standard deviation (SD).

\subsection{In Silico Analysis of Antioxidant Peptides on MPO Inhibition}

Several molecular docking studies targeting specific enzyme inhibition effects have been recently published $[27,28]$. Among the docking tools, CDOCKER, a CHARMm-based docking algorithm [29], found favorable docking poses between small molecules and target proteins using their structural characteristics, such as unshared electron pairs, double bonds, hydrophobicity, and charge.

To verify the antioxidant activity of bioactive peptides purified from TVP-GFC-3, the biological network dynamics of bioactive peptides and MPO were simulated in a computational space, and its binding energies were compared with thiocyanate ion, a pseudohalide anion, and 4-aminobenzoic acid hydrazide (4-ABH), an inhibitor of MPO. In silico analysis was performed using the crystalline structure of MPO (PDB ID 7LAL) and 4-ABH (PubChem CID 21450). Bioactive peptide structures were drawn using a CDOCKER tool. Each amino acid of bioactive peptides forms diverse hydrogen and pi bonds; also, all bioactive peptides dock to the active site of MPO with a more stable binding energy than that of thiocyanate ion (Figure 5, Table 4). All of the bioactive peptides form the hydrogen bonds and/or pi bonds with a heme group. The activation of MPO is required a heme group as a cofactor [30]. 
A

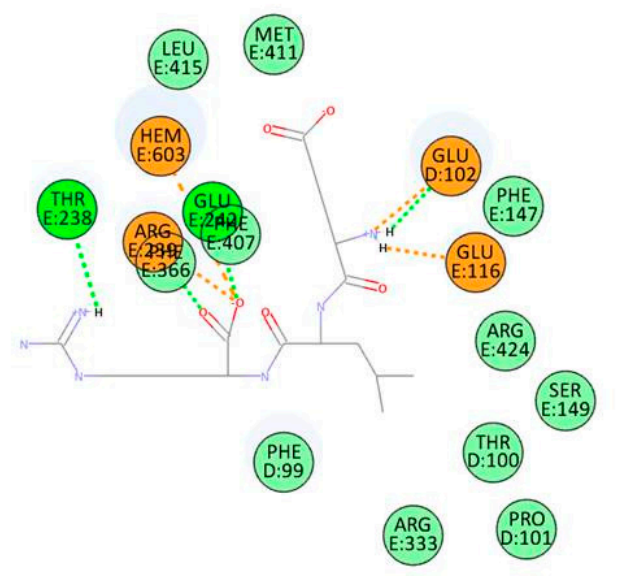

C

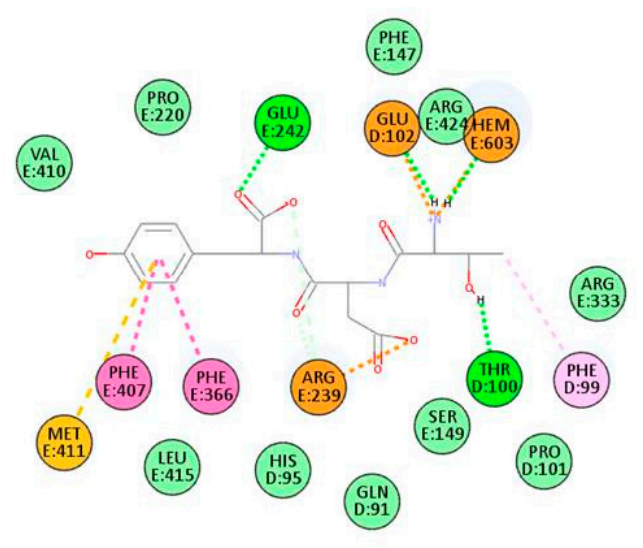

E
B

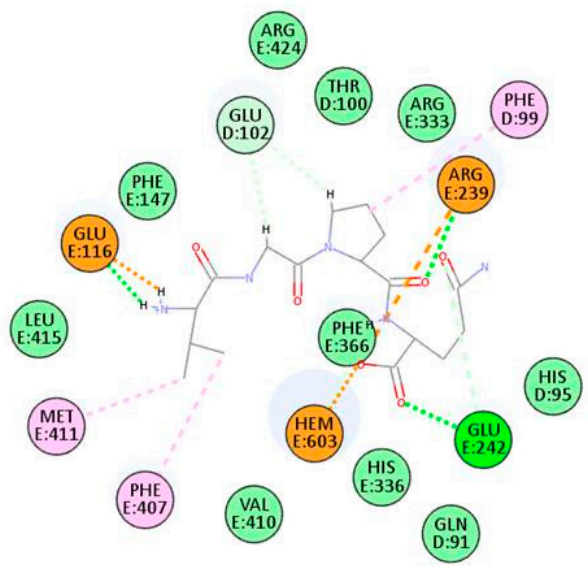

D
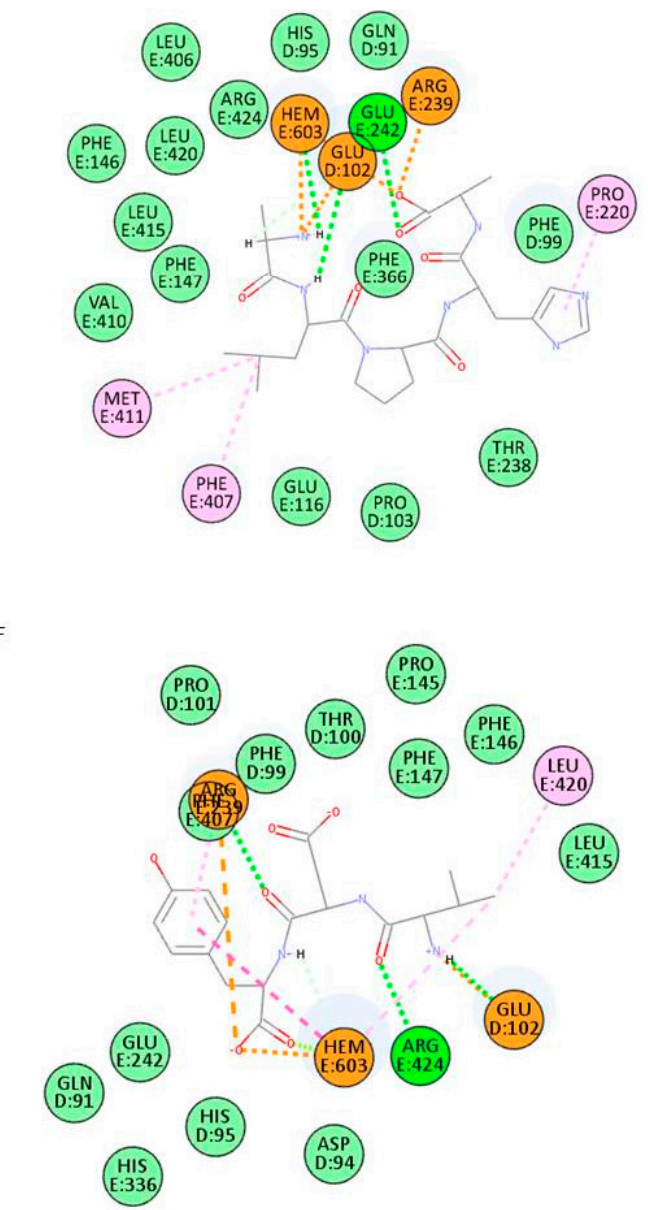

Figure 5. Cont. 


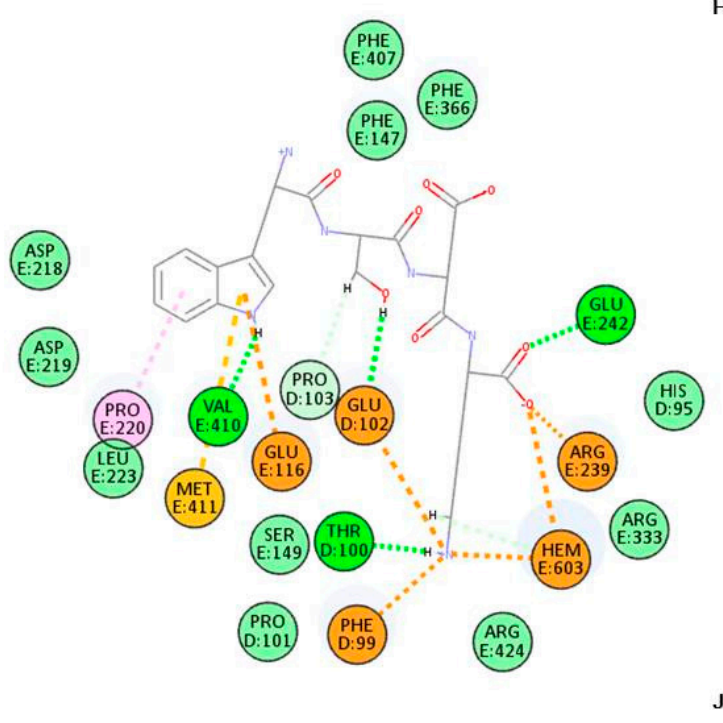

H

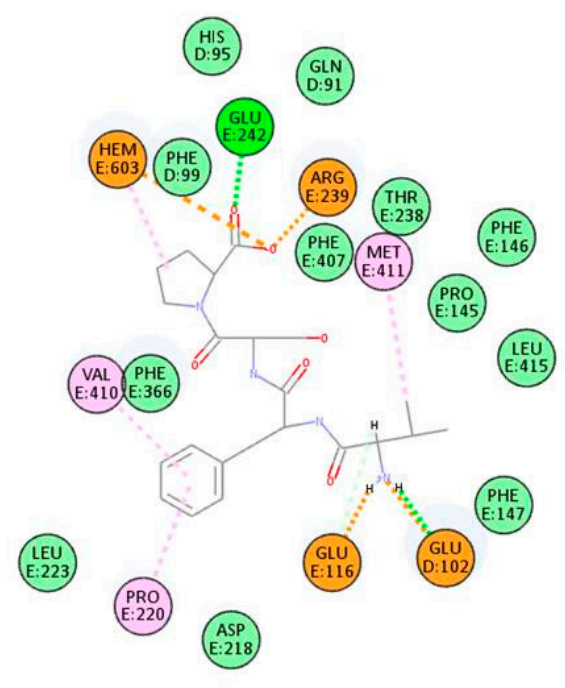

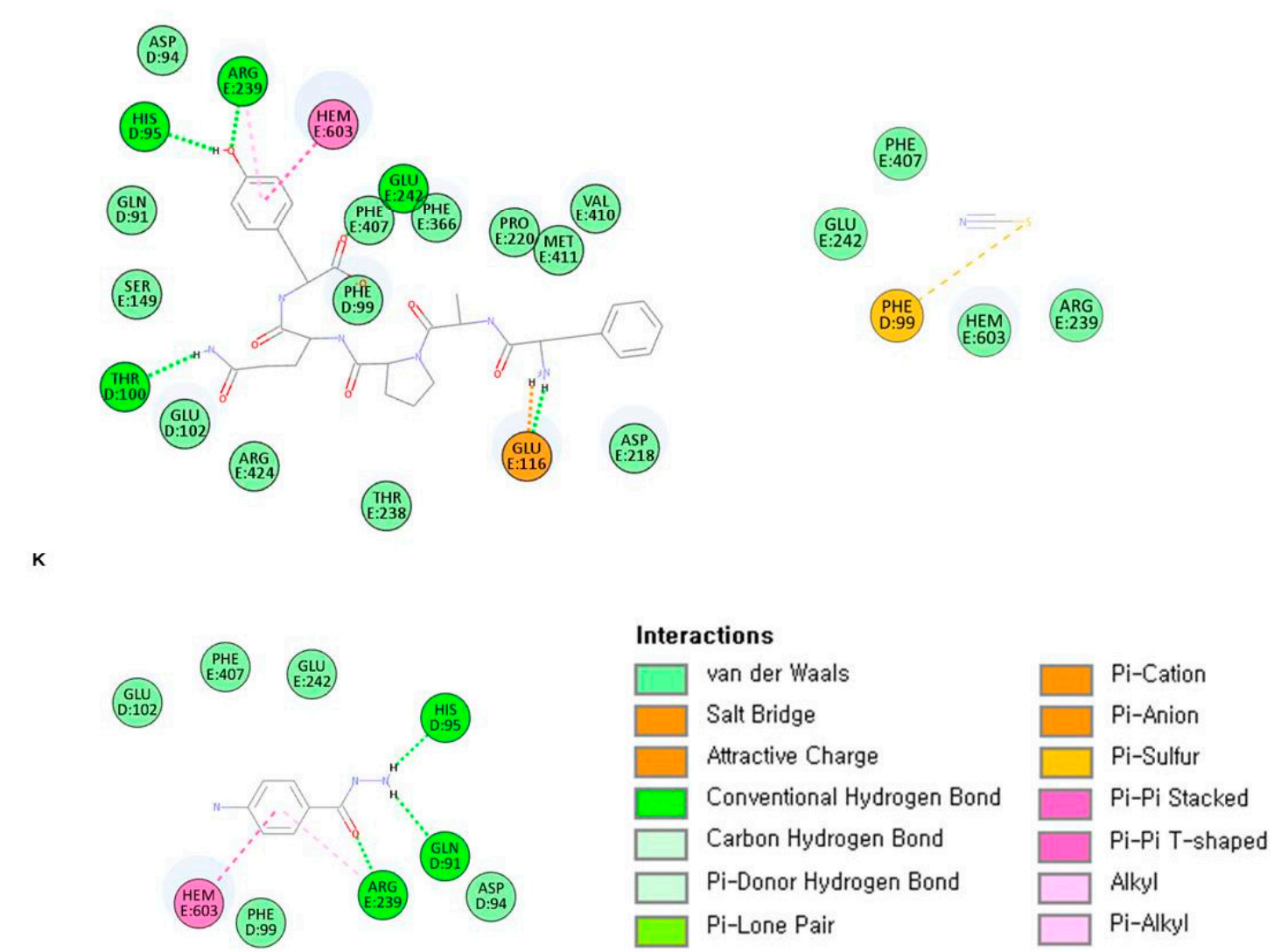

Figure 5. 2D diagrams of bioactive peptides-MPO complexes. ELR (A), VGPQ (B), TDY (C), ALPAH (D), PAH (E), VDY (F), $\operatorname{WSDK}(\mathbf{G}), \operatorname{VFSP}(\mathbf{H})$, FAPQY $(\mathbf{I})$, thiocyanate ion $(\mathbf{J})$, and 4-aminobenzoic acid hydrazide (4-ABH) (K). 
Table 4. Docking results bioactive peptide-MPO complexes.

\begin{tabular}{|c|c|c|}
\hline \multirow{2}{*}{ Sample } & \multicolumn{2}{|c|}{ Characteristic of Peptide-MPO Complexes } \\
\hline & $\begin{array}{l}\text { Binding Energy } \\
(\mathrm{kcal} / \mathrm{mol})\end{array}$ & Main Bonding \\
\hline ELR & -426.358 & $\begin{array}{l}\text { HEM603, GLU102, GLU116, THR238, } \\
\text { ARG239, GLU242, PHE366, PHE407 }\end{array}$ \\
\hline VGPQ & -509.950 & $\begin{array}{l}\text { HEM603, PHE99, GLU102, GLU116, ARG239, } \\
\text { GLU242, PHE366, PHE407, MET411 }\end{array}$ \\
\hline TDY & -368.111 & $\begin{array}{l}\text { HEM603, PHE99, THR100, GLU102, ARG239, } \\
\text { GLU242, PHE366, PHE407, MET411 }\end{array}$ \\
\hline ALPAH & -360.686 & $\begin{array}{c}\text { HEM603, GLU102, PRO220, ARG239, } \\
\text { GLU242, PHE407, MET411 }\end{array}$ \\
\hline PAH & -430.944 & $\begin{array}{l}\text { HEM603, PHE99, GLU102, PRO103, PHE147, } \\
\text { GLU242 }\end{array}$ \\
\hline VDY & -398.554 & $\begin{array}{c}\text { HEM603, GLU102, ARG239, PHE407, } \\
\text { LEU420, ARG424 }\end{array}$ \\
\hline WSDK & -340.875 & $\begin{array}{c}\text { HEM603, PHE99, THR100, GLU102, PRO103, } \\
\text { GLU116, PRO220, ARG239, GLU242, } \\
\text { VAL410, MET411 }\end{array}$ \\
\hline VFSP & -442.737 & $\begin{array}{l}\text { HEM603, GLU102, GLU116, PRO220, } \\
\text { ARG239, GLU242, VAL410, MET411 }\end{array}$ \\
\hline FAPQY & -387.049 & $\begin{array}{l}\text { HEM603, HIS95, THR100, GLU116, ARG239, } \\
\text { GLU242 }\end{array}$ \\
\hline Thiocyanate ion & -33.0451 & PHE99 \\
\hline $\begin{array}{l}\text { 4-aminobenzoic acid } \\
\text { hydrazide }(4-\mathrm{ABH})\end{array}$ & -74.8248 & HEM603, GLN91, HIS95, ARG239 \\
\hline
\end{tabular}

4- $\mathrm{ABH}$ is one of hydrazide with the formula $\mathrm{H}_{2} \mathrm{NC}_{6} \mathrm{H}_{4} \mathrm{C}(\mathrm{O}) \mathrm{NHNH}_{2}$ containing two amino groups and benzene ring. 4- $\mathrm{ABH}$ is docking to the active site of MPO with hydrogen bond and pi bond between the amino groups and benzene ring. Among the bioactive peptides, TDY and FAPQY having a benzene ring bound to MPO, with low binding energy of -368.111 and $-387.049 \mathrm{kcal} / \mathrm{mol}$, respectively. The top hit docking poses were presented as two-dimensional (2D) diagrams and three-dimensional (3D) to confirm the biological network dynamics of the complexes (Figures 5 and 6). MPO was expressed as a line model, and the active site including a heme group (green part), was expressed as a thin stick model (Figure 6). TDY (Figure 6A) and FAPQY (Figure 6B) was shown as a gray and red stick model. The complexes displayed favorable hydrogen bond interactions, with the pink section as a donor and the green section as an acceptor (Figure 6A,B). The docking of TDY was performed through interaction with the active site, including a heme group and PHE99, THR100, GLU102, ARG239, GLU242, PHE366, PHE407, and MET411 (Figures 5C and $6 \mathrm{~A}$ ). In addition, the docking of FAPQY was performed through interaction with the active site, including a heme group and HIS95, THR100, GLU116, ARG239, and GLU242 (Figures 5I and 6B). Especially, FAPQY formed the similar binding pose with 4-ABH-MPO complex by combining as pi bonds between a benzene ring and a heme group and ARG239 (Figures 5K and 6C). 
A
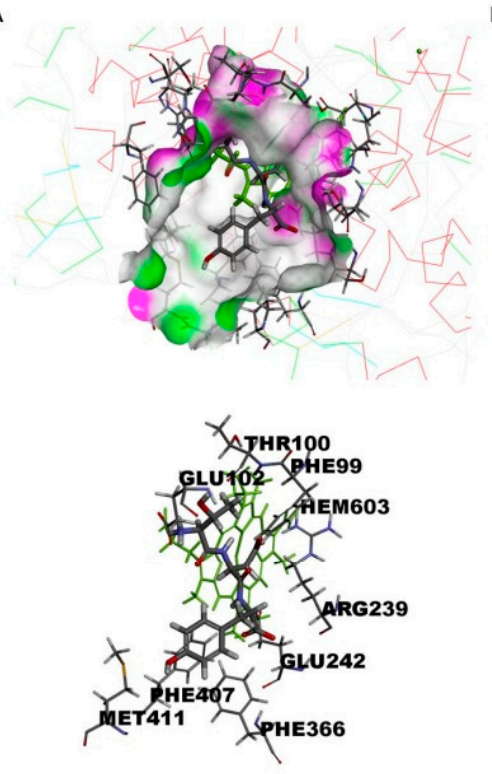

D

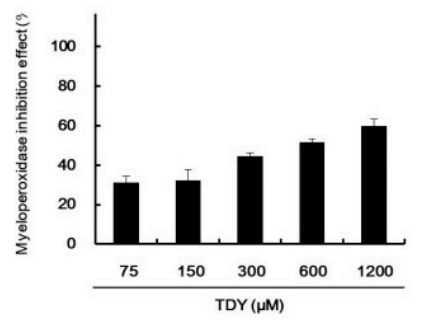

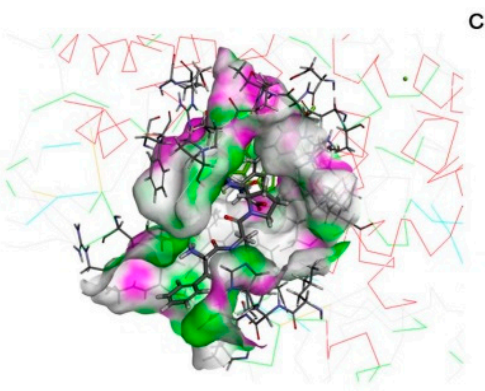
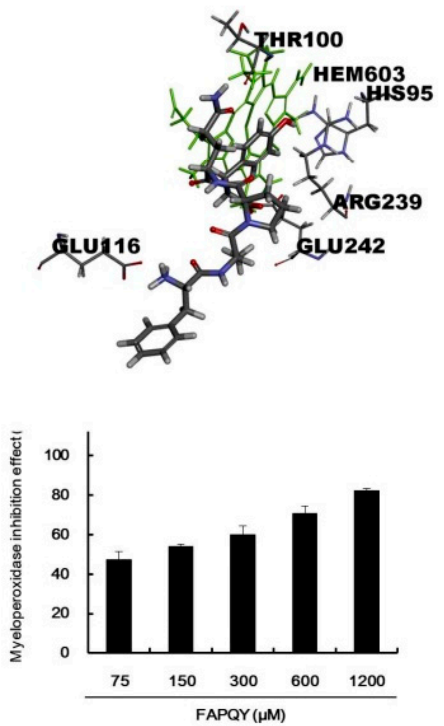
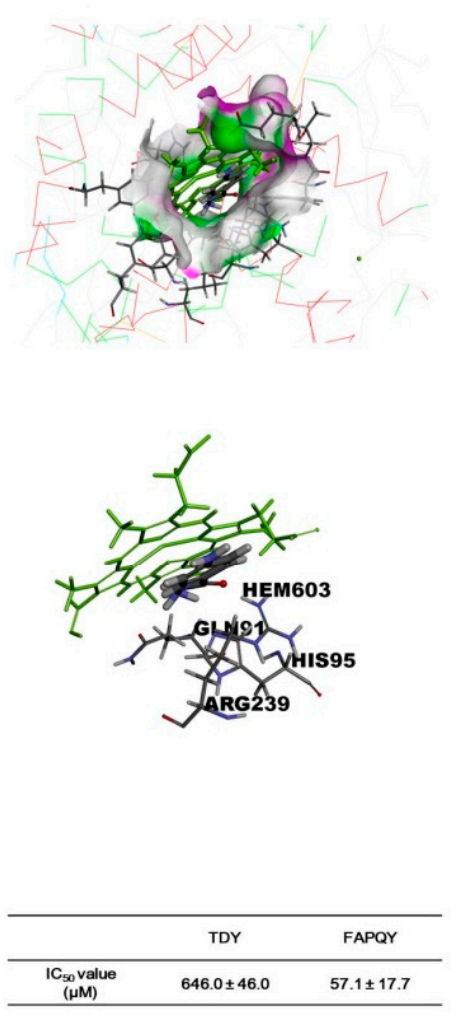

Figure 6. Myeloperoxidase (MPO) inhibition effects of TDY and FAPQY. (A-C) TDY, FAPQY, and 4-aminobenzoic acid hydrazide (4-ABH) are shown as a gray and red stick model. MPO is shown as a line model, and the active site of MPO is shown in the thin stick model. (A) The favorable hydrogen bond interactions of the TDY-MPO complex. (B) The favorable hydrogen bond interactions of the FAPQY-MPO complex. (C) The favorable hydrogen bond interactions of 4-ABH-MPO complex. (D) MPO inhibition effects of TDY and FAPQY in in vitro analysis. (E) $\mathrm{IC}_{50}$ values on MPO inhibition effect of TDY and FAPQY.

\subsection{In Vitro Analysis of Antioxidant Peptides on Myeloperoxidase (MPO) Inhibition}

To confirm the in silico prediction results on the docking of peptides to MPO, in vitro MPO inhibition effects of the peptides were assessed. Both TDY and FAPQY inhibited $\mathrm{MPO}$ in a concentration-dependent manner, and the $\mathrm{IC}_{50}$ values were calculated to be $646.0 \pm 45.0 \mu \mathrm{M}$ and $57.1 \pm 17.7 \mu \mathrm{M}$, respectively (Figure $6 \mathrm{D}, \mathrm{E}$ ). These results indicated that these bioactive peptides possessed the values of the natural MPO inhibitors. MPO promotes oxidative stress by involving the generation of radicals [31]. As with many radical species, $\mathrm{H}_{2} \mathrm{O}_{2}$ can cause the oxidative stress, directly reacting the cells and/or indirectly inducing the production other radical species. Especially, the hypohalous acids were produced by the $\mathrm{MPO}$ with $\mathrm{H}_{2} \mathrm{O}_{2}$; these radicals cause the stronger oxidative stress. In addition, the scavenging of $\mathrm{H}_{2} \mathrm{O}_{2}$ affects to inhibit the MPO activities. Thus, the components having both $\mathrm{H}_{2} \mathrm{O}_{2}$ scavenging activity and MPO inhibition effects can be considered as valuable antioxidant. Therefore, the protamex-assisted extracts and peptide from T. cornutus having both $\mathrm{H}_{2} \mathrm{O}_{2}$ scavenging activity and MPO inhibition effects can be used as functional food components for human health.

\section{Materials and Methods}

\subsection{Materials}

T. cornutus was purchased from a fishing village in Taeheung in May 2019 (Jeju, Korea) and was washed thrice with tap water to remove salt, epiphytes, and sand attached to its surface. The viscera and muscle tissues were separated and carefully rinsed using 
fresh water and stored at $-20{ }^{\circ} \mathrm{C}$. Finally, the T. cornutus viscera and muscle tissues were freeze-dried and finely ground before hydrolysis. Commercial food-grade proteases, including alcalase 2.4 L FG, neutrase $0.8 \mathrm{~L}$, flavourzyme $500 \mathrm{MG}$, and protamex, were purchased from Novo Co. (Novozyme Nordisk, Bagasvaerd, Denmark). Other proteases that contain pepsin, trypsin, $\alpha$-chymotrypsin bromelain, and papain were purchased from Sigma Chemical Co. (St. Louis, MO, USA). The characterized peptide was synthesized by Anygen Co., LTD. (Gwangju, Korea) based on its amino acid sequence. Other chemicals and reagents used were of analytical grade.

\subsection{Proximate Composition of T. cornutus}

The proximate composition of $T$. cornutus was determined following the AOAC method [32]. Crude protein was determined using the Kjeldahl method, and crude lipid was performed using the Soxhlet method. In addition, moisture was determined by keeping the sample in a dry oven, and crude ash was prepared at $550{ }^{\circ} \mathrm{C}$ in a dry-type furnace.

\subsection{Amino Acid Profile}

Amino acid compositions were analyzed according to a previously developed HPLC method [33]. The samples were added $30 \mathrm{~mL}$ of $6 \mathrm{~N} \mathrm{HCl}$ and the mixtures were incubated for $24 \mathrm{~h}$ at $130{ }^{\circ} \mathrm{C}$. The mixtures were filtered with $0.45 \mu \mathrm{m}$ syringe filter, and used for HPLC sample. The HPLC system for analysis was consisted of an Ultimate3000 (Thermo Fisher Scientific, MA, USA) and FL detector 1260FLD (Agilent Technologies, Inc., Santa Clara, CA, USA). The analyses were carried out using a binary gradient mode. The mobile phase (A) was $40 \mathrm{mM}$ sodium phosphate buffer $(\mathrm{pH} 7)$ and (B) was water:acetonitrile:methanol:water (10:45:45): $0 \mathrm{~min}, 5 \% \mathrm{~B}$; 0-3 $\mathrm{min}, 5 \% \mathrm{~B} ; 3-24 \mathrm{~min}, 55 \% \mathrm{~B} ; 24-25 \mathrm{~min}, 80 \% \mathrm{~B} ; 25-31 \mathrm{~min}$, $80 \% \mathrm{~B} ; 31-34.5 \mathrm{~min}, 5 \% \mathrm{~B} ; 34.5-35 \mathrm{~min}, 5 \% \mathrm{~B}$. The column temperature was kept at $40{ }^{\circ} \mathrm{C}$, and the flow rate was $1.5 \mathrm{~mL} / \mathrm{min}$. An Inno C18 column $(4.6 \times 150 \mathrm{~mm}, 5 \mu \mathrm{m}$, YoungJin biochrom, Gyeonggi, Korea) was used. The chromatogram was detected using a fluorescence spectrophotometer at 340/450 nm (o-phthalaldehyde) and 266/305 nm (9-fluorenylmethyl chloroformate) and an absorbance at $338 \mathrm{~nm}$.

\subsection{Preparation of T. cornutus Enzyme-Assisted Extracts}

T. cornutus viscera and muscle enzyme-assisted hydrolysis was performed according to the method used by Ko et al. [34] and Heo et al. [35]. Hydrolytic enzymes were prepared using four food-grade proteases (alcalase, flavourzyme, neutrase, and protamex), three digestive enzymes (pepsin, trypsin, and $\alpha$-chymotrypsin), and two plant-derived digestive enzymes (bromelain and papain). Two grams of the dried ground T. cornutus viscera and muscle powder was homogenized with buffer $(100 \mathrm{~mL})$ and hydrolyzed with enzymes in a substrate/enzyme ratio of 100:1 (w/w). The $\mathrm{pH}$ of the homogenates was adjusted to its optimal $\mathrm{pH}$ value before enzymatic hydrolysis. Enzymatic reactions were performed for $24 \mathrm{~h}$ to achieve an optimal degree of enzymatic hydrolysis. Then, the extracts were boiled for $10 \mathrm{~min}$ at $100{ }^{\circ} \mathrm{C}$ in a water bath to inactivate the enzyme. Each extract was clarified by centrifugation $\left(3500 \mathrm{rpm}, 20 \mathrm{~min}\right.$ at $4{ }^{\circ} \mathrm{C}$ ) to remove the residue. All extracts were freeze-dried and kept at $-20^{\circ} \mathrm{C}$. The yields of each T. cornutus viscera and muscle enzyme-assisted extracts were calculated as the percentage of dry weight compared with the hydrolyzed sample weight. Briefly, extract yields were determined by subtracting the dried weight of the residue from $1 \mathrm{~mL}$ of dried extracts and were expressed as a percentage.

\subsection{Separation of Fractions and Radical Scavenging Properties}

Radical scavenging properties were separated as previously described by Kang et al. [6]. The extracts showing antioxidant activities were dissolved in distilled water, loaded onto a Sephadex G-25 gel filtration column $(2.5 \times 75 \mathrm{~cm})$, and equilibrated with distilled water. The column was eluted with distilled water at a flow rate of $1.0 \mathrm{~mL} / \mathrm{min}$. Elution peaks were detected at $280 \mathrm{~nm}$. 


\subsection{Characterization of the Separated Antioxidant Properties}

The molecular mass and amino acid sequence of the separated antioxidant properties from T. cornutus was determined using a MicroQ-TOF tandem mass spectrometer (Bruker Daltonics, 255748 Bremen, Germany) coupled with a nanoelectrospray ionization (ESI) source. The fraction dissolved in water was infused into the ESI source, and the molecular weight was determined by doubly charged $(\mathrm{M}+2 \mathrm{H})^{2+}$ state analysis in the mass spectrum. Following molecular weight determination, the peptides were automatically selected for fragmentation, and sequence information was obtained by tandem MS analysis.

\section{7. $\mathrm{H}_{2} \mathrm{O}_{2}$ Scavenging Activity}

$\mathrm{H}_{2} \mathrm{O}_{2}$ scavenging activity was determined according to the method of Müller [36]. One hundred microliters of 0.1-M phosphate buffer ( $\mathrm{pH}$ 5.0) and twenty microliters of the sample solution were mixed in a 96-well plate. Twenty microliters of $\mathrm{H}_{2} \mathrm{O}_{2}$ was added to the mixture and then incubated at $37^{\circ} \mathrm{C}$ for $5 \mathrm{~min}$. After incubation, $30 \mu \mathrm{L}$ of $1.25 \mathrm{mM}$ ABTS and $30 \mu \mathrm{L}$ of peroxidase ( $1 \mathrm{unit} / \mathrm{mL}$ ) was added to the mixture and then incubated at $37^{\circ} \mathrm{C}$ for $10 \mathrm{~min}$. The absorbance was read with a microplate reader at $405 \mathrm{~nm}$.

\subsection{Cell Line and Cell Culture}

HepG2 cells were purchased from the Korean Cell Line Bank (Seoul, Korea). HepG2 cells were cultured in RPMI-1640 medium, supplemented with 10\% fetal bovine serum, $1 \%$ streptomycin $(100 \mu \mathrm{g} / \mathrm{mL})$, and penicillin $(100 \mathrm{unit} / \mathrm{mL})$ and maintained at $37^{\circ} \mathrm{C}$ in a $5 \%$ $\mathrm{CO}_{2}$ incubator.

\subsection{Determination of Cell Viability and ROS Generation in $\mathrm{H}_{2} \mathrm{O}_{2}$-Treated HepG2 Cells}

Potential antioxidant activities were evaluated under $\mathrm{H}_{2} \mathrm{O}_{2}$-induced oxidative conditions. Briefly, HepG2 cells were plated in 96-well plates at a concentration of $1 \times 10^{5}$ cells $/ \mathrm{mL}$ and incubated for $24 \mathrm{~h}$. After $24 \mathrm{~h}$ of incubation, the samples were treated before activating them with $\mathrm{H}_{2} \mathrm{O}_{2}(1 \mathrm{mM})$ for $1 \mathrm{~h}$. After $24 \mathrm{~h}$ of incubation, cell viability was measured using the MTT assay [37]. The intracellular ROS scavenging activity was analyzed using the DCF-DA assay [38]. The HepG2 cells were seeded as shown before, treated with $\mathrm{H}_{2} \mathrm{O}_{2}$ and different concentrations of samples, and incubated for $24 \mathrm{~h}$. After $24 \mathrm{~h}$ of incubation, $500 \mu \mathrm{g} / \mathrm{mL}$ of DCF-DA was added to each well. Finally, DCF-DA fluorescence was measured using a Synergy HT Multi-Detection Microplate Reader (BioTek Instruments, Winooski, VT, USA) at excitation and emission wavelengths of 485 and $535 \mathrm{~nm}$, respectively.

\subsection{In Silico Analysis of MPO Inhibition}

For molecular docking studies, the crystal structures of MPO (ID: 7LAL) were provided by the Protein Data Bank. The structures of nine bioactive peptides derived from TVP were drawn using a CDOCKER tool. The docking of bioactive peptides to MPO was performed using the CDOCKER tool in Discovery Studio 2020 (Dassault Systemes, Velizy-Villacoublay, France). The simulation was performed as follows: (1) a 2D structure was converted into a 3D structure; (2) receptors were prepared, and the binding site was defined; and (3) the docking of compounds was performed using a CDOCKER tool [28]. The binding energies of the produced complexes were calculated to compare the optimal agents among the bioactive peptides, inhibitors, and existing ligand (thiocyanate ion). The docking poses of bioactive peptides to MPO were expressed as 2D diagrams and 3D crystalline structures.

\subsection{MPO Inhibition Effect}

MPO inhibition effects of the peptides were measured by using an MPO inhibitor screening assay kit (Abcam PLC, Cambridge, UK) following the instruction in the enclosed user manuals. Briefly, $10 \mu \mathrm{L}$ of each peptide, $10 \mu \mathrm{L}$ of $1.25 \mu \mathrm{L} / \mathrm{mL}$ MPO and $40 \mu \mathrm{l}$ of assay buffer were mixed in a 96-well black plate. $50 \mu \mathrm{L}$ of the peroxidation initiator solution was quickly added to all of the wells and then incubated for $5 \mathrm{~min}$ at RT. After incubation, the 
fluorescence intensity of the each well was read using an excitation wavelength of $530 \mathrm{~nm}$ and an emission wavelength of $590 \mathrm{~nm}$.

\subsection{Statistical Analysis}

All data were represented as the mean \pm standard deviation of three determinations. The statistical comparison of the mean values was performed by one-way ANOVA, followed by Tukey's multiple comparisons test. Statistical significance was considered at $p<0.01$.

\section{Conclusions}

By the sea food industrial activities, a considerable amount of fishery resources are discarded as processing leftovers including viscera. Thus, the possibility to recover such a material and convert it in a value-added product would be highly desirable. In Korea, T. cornutus muscle tissues are used in local foods, but most of the viscera tissues were discarded. T. cornutus viscera is a rich protein source, with more than $50 \%$ of protein contents composed of essential amino acids, such as histidine, threonine, valine, methionine, phenylalanine, isoleucine, leucine, and lysine. In addition, the potential antioxidant properties from $T$. cornutus viscera extracts possessed $\mathrm{H}_{2} \mathrm{O}_{2}$ scavenging activity and protective effects on oxidative stress in $\mathrm{H}_{2} \mathrm{O}_{2}$-treated HepG2 cells. The potential antioxidant properties were composed of nine bioactive peptides. In addition, in silico analysis predicted that the nine bioactive peptides inhibit peroxidase by interacting with the surface of MPO close to the active site. Especially, TDY and FAPQY showed the MPO inhibition effects with $\mathrm{IC}_{50}$ values of $646.0 \pm 45.0 \mu \mathrm{M}$ and $57.1 \pm 17.7 \mu \mathrm{M}$, respectively. These results indicated that the potential antioxidant properties from T. cornutus viscera could be used for functional food components for human health.

Supplementary Materials: The following are available online at https:/ / www.mdpi.com/article / 10.3390/md19100567/s1. Figure S1: LC-MS/MS chromatogram of TVP-GFC-3. Supplementary Figures S2-S10: MS/MS sequencing of bioactive peptides.

Author Contributions: Conceptualization, N.K. and S.-J.H.; Data curation, E.-A.K. and J.K.; Formal analysis, N.K. and S.-H.L.; Investigation, E.-A.K.; Methodology, J.K.; Project administration, S.-J.H.; Resources, S.-J.H.; Supervision, S.-H.L. and S.-J.H.; Validation, E.-A.K.; Software, N.K.; Visualization, N.K.; Writing—original draft preparation, N.K.; Writing—review and editing, S.-H.L. and S.-J.H. All authors have read and agreed to the published version of the manuscript.

Funding: The research was the project titled "Diagnosis, treatment and control technology based on big data of infectious virus in marine environment" funded by the Korea Institute of Marine Science \& Technology Promotion (Ref. No. 21210466) in the Ministry of Oceans and Fisheries (MOF) of South Korea. In addition, this research was financially supported by a research grants from the Korea Institute of Ocean Science and Technology (PE99922).

Institutional Review Board Statement: Not applicable.

Acknowledgments: We would like to acknowledge Choung-Ryong Fisheries, Inc. for helping with coordination of relations with a fishing village and collection of T. cornutus materials.

Conflicts of Interest: The authors declare no conflict of interest.

\section{References}

1. Chung, S.C.; Lee, J.J.; Lee, C.K. A study on the growth of Jeju Island's Turban Shell, Turbo cornutus. Bull. Mar. Resour. Res. Inst. 1983, 7, 71-75.

2. Chang, D.S. Studies on the stock assessment and management of the Turban Shell, Batillus cornutus in Jeju Coastal water, Korea. Ph.D. Thesis, Cheju National University, Cheju, Korea, 2002.

3. Chung, S.C. Studies on the biometry of the Turbo cornutus solander in the Cheju coastal waters. Bull. Mar. Biol. Stn. 1976, 1, 3-9.

4. Yoo, J.T.; Oh, B.S.; Chang, D.S. Preference of adult top shell (Batillus cornutus) on specific marine algae in the coastal waters of Jeju Island. Korean J. Malacol. 2011, 27, 299-306. [CrossRef]

5. Zou, Z.; Chang, H.; Li, H.; Wang, S. Induction of reactive oxygen species: An emerging approach for cancer therapy. Apoptosis 2017, 22, 1321-1335. [CrossRef] [PubMed] 
6. Kang, N.; Ko, S.C.; Samarakoon, K.; Kim, E.A.; Kang, M.C.; Lee, S.C.; Kim, J.; Kim, Y.T.; Kim, J.S.; Kim, H. Purification of antioxidative peptide from peptic hydrolysates of Mideodeok (Styela clava) flesh tissue. Food Sci. Biotechnol. 2013, $22,541-547$. [CrossRef]

7. Sroka, Z.; Cisowski, W. Hydrogen peroxide scavenging, antioxidant and anti-radical activity of some phenolic acids. Food Chem. Toxicol. 2003, 41, 753-758. [CrossRef]

8. Ielciu, I.; Mouithys-Mickalad, A.; Franck, T.; Angenot, L.; Ledoux, A.; Păltinean, R.; Cieckiewicz, E.; Etienne, D.; Tits, M.; Crişan, G. Flavonoid composition, cellular antioxidant activity and (myelo) peroxidase inhibition of a Bryonia alba L.(Cucurbitaceae) leaves extract. J. Pharm. Pharmacol. 2019, 71, 230-239. [CrossRef] [PubMed]

9. Ulfig, A.; Leichert, L.I. The effects of neutrophil-generated hypochlorous acid and other hypohalous acids on host and pathogens. Cell. Mol. Life Sci. 2021, 78, 385-414. [CrossRef] [PubMed]

10. Gülçin, Ý.; Elias, R.; Gepdiremen, A.; Boyer, L.; Köksal, E. A comparative study on the antioxidant activity of fringe tree (Chionanthus virginicus L.) extracts. Afr. J. Biotechnol. 2007, 6, 410-418.

11. Rees, M.D.; Bottle, S.E.; Fairfull-Smith, K.E.; Malle, E.; Whitelock, J.M.; Davies, M.J. Inhibition of myeloperoxidase-mediated hypochlorous acid production by nitroxides. Biochem. J. 2009, 421, 79-86. [CrossRef]

12. Pap, R.; Pandur, E.; Jánosa, G.; Sipos, K.; Agócs, A.; Deli, J. Lutein exerts antioxidant and anti-Inflammatory effects and influences iron utilization of BV-2 microglia. Antioxidants 2021, 10, 363. [CrossRef] [PubMed]

13. Ozogul, F.; Cagalj, M.; Šimat, V.; Ozogul, Y.; Tkaczewska, J.; Hassoun, A.; Kaddour, A.A.; Kuley, E.; Rathod, N.B.; Phadke, G.G. Recent developments in valorisation of bioactive ingredients in discard/seafood processing by-products. Trends Food Sci. Technol. 2021, 116, 559-582. [CrossRef]

14. Pal, G.K.; Suresh, P.V. Sustainable valorisation of seafood by-products: Recovery of collagen and development of collagen-based novel functional food ingredients. Innov. Food Sci. Emerg. Technol. 2016, 37, 201-215. [CrossRef]

15. Sila, A.; Bougatef, A. Antioxidant peptides from marine by-products: Isolation, identification and application in food systems. A review. J. Funct. Foods 2016, 21, 10-26. [CrossRef]

16. Xu, D.P.; Li, Y.; Meng, X.; Zhou, T.; Zhou, Y.; Zheng, J.; Zhang, J.J.; Li, H.B. Natural antioxidants in foods and medicinal plants: Extraction, assessment and resources. Int. J. Mol. Sci. 2017, 18, 96. [CrossRef] [PubMed]

17. Rustad, T.; Storrø, I.; Slizyte, R. Possibilities for the utilisation of marine by-products. Int. J. Food Sci. Technol. 2011, 46, 2001-2014. [CrossRef]

18. Arvanitoyannis, I.S.; Kassaveti, A. Fish industry waste: Treatments, environmental impacts, current and potential uses. Int. J. Food Sci. Technol. 2008, 43, 726-745. [CrossRef]

19. Kim, S.K.; Venkatesan, J. Introduction to Seafood Processing by-Products. Seafood Processing by-Products; Springer: Berlin/Heidelberg, Germany, 2014; pp. 1-9.

20. Shahidi, F.; Varatharajan, V.; Peng, H.; Senadheera, R. Utilization of marine by-products for the recovery of value-added products. J. Food Bioact. 2019, 6, 10-61. [CrossRef]

21. Klomklao, S.; Benjakul, S. Utilization of tuna processing byproducts: Protein hydrolysate from skipjack tuna (Katsuwonus pelamis) viscera. J. Food Process. Preserv. 2017, 41, e12970. [CrossRef]

22. Oh, J.Y.; Kim, E.A.; Lee, H.; Kim, H.S.; Lee, J.S.; Jeon, Y.J. Antihypertensive effect of surimi prepared from olive flounder (Paralichthys olivaceus) by angiotensin-I converting enzyme (ACE) inhibitory activity and characterization of ACE inhibitory peptides. Process. Biochem. 2019, 80, 164-170. [CrossRef]

23. Regenstein, J.; Zhou, P. Collagen and gelatin from marine by-products. In Maximising the Value of Marine by-Products; Elsevier: Amsterdam, The Netherlands, 2007; pp. 279-303.

24. Kim, S.K.; Mendis, E. Bioactive compounds from marine processing byproducts-A review. Food Res. Int. 2006, $39,383-393$. [CrossRef]

25. Jang, M.S.; Jang, J.R.; Park, H.Y.; Yoon, H.D. Overall composition, and levels of fatty acids, amino acids, and nucleotide-type compounds in wild abalone Haliotis gigantea and cultured abalone Haliotis discus hannai. Korean J. Food Preserv. 2010, 17, 533-540.

26. Xia, T.; Yao, J.; Zhang, J.; Zheng, Y.; Song, J.; Wang, M. Protective effects of Shanxi aged vinegar against hydrogen peroxide-induced oxidative damage in LO2 cells through Nrf2-mediated antioxidant responses. RSC Adv. 2017, 7, 17377-17386. [CrossRef]

27. Kang, N.; Lee, J.H.; Lee, W.; Ko, J.Y.; Kim, E.A.; Kim, J.S.; Heu, M.S.; Kim, G.H.; Jeon, Y.J. Gallic acid isolated from Spirogyra sp. improves cardiovascular disease through a vasorelaxant and antihypertensive effect. Environ. Toxicol. Pharmacol. 2015, 39, 764-772. [CrossRef] [PubMed]

28. Kang, N.; Ko, S.C.; Kim, H.S.; Yang, H.W.; Ahn, G.; Lee, S.C.; Lee, T.G.; Lee, J.S.; Jeon, Y.J. Structural evidence for antihypertensive effect of an antioxidant peptide purified from the edible marine animal Styela clava. J. Med. Food 2020, 23, 132-138. [CrossRef]

29. Wu, G.; Robertson, D.H.; Brooks, C.L., III; Vieth, M. Detailed analysis of grid-based molecular docking: A case study of CDOCKER-A CHARMm-based MD docking algorithm. J. Comput. Chem. 2003, 24, 1549-1562. [CrossRef] [PubMed]

30. Heinecke, J.W.; Li, W.; Francis, G.A.; Goldstein, J.A. Tyrosyl radical generated by myeloperoxidase catalyzes the oxidative cross-linking of proteins. J. Clin. Investig. 1993, 91, 2866-2872. [CrossRef] [PubMed]

31. Baali, N.; Mezrag, A.; Bouheroum, M.; Benayache, F.; Benayache, S.; Souad, A. Anti-inflammatory and Antioxidant Effects of Lotus corniculatus on Paracetamol-induced Hepatitis in Rats. Anti-Inflamm. Anti-Allergy Agents Med. Chem. 2020, 19, 128-139. [CrossRef] [PubMed] 
32. Helrich, K. Official Methods of Analysis of the Association of Official Analytical Chemists; Association of Official Analytical Chemists: Arlington, VA, USA, 1990.

33. Herbert, P.; Santos, L.; Alves, A. Simultaneous quantification of primary, secondary amino acids, and biogenic amines in musts and wines using OPA/3-MPA/FMOC-CI fluorescent derivatives. J. Food Sci. 2001, 66, 1319-1325. [CrossRef]

34. Ko, S.C.; Lee, J.K.; Byun, H.G.; Lee, S.C.; Jeon, Y.J. Purification and characterization of angiotensin I-converting enzyme inhibitory peptide from enzymatic hydrolysates of Styela clava flesh tissue. Process Biochem. 2012, 47, 34-40. [CrossRef]

35. Heo, S.J.; Park, E.J.; Lee, K.W.; Jeon, Y.J. Antioxidant activities of enzymatic extracts from brown seaweeds. Bioresour. Technol. 2005, 96, 1613-1623. [CrossRef] [PubMed]

36. Müller, H.E. Detection of hydrogen peroxide produced by microorganisms on an ABTS peroxidase medium. Zent. Bakteriol. 1985, 259, 151-154. [CrossRef]

37. Han, E.J.; Fernando, I.P.S.; Kim, E.A.; Kim, J.; Jung, K.; Kim, S.Y.; Cha, S.H.; Kim, K.N.; Heo, S.J.; Ahn, G. 5-Bromo-3, 4dihydroxybenzaldehyde from Polysiphonia morrowii attenuate IgE/BSA-stimulated mast cell activation and passive cutaneous anaphylaxis in mice. Biochem. Pharmacol. 2020, 178, 114087-114096. [CrossRef] [PubMed]

38. Ding, Y.; Jiratchayamaethasakul, C.; Kim, E.A.; Kim, J.; Heo, S.J.; Lee, S.H. Hyaluronidase inhibitory and antioxidant activities of enzymatic hydrolysate from Jeju Island red sea cucumber (Stichopus japonicus) for novel anti-aging cosmeceuticals. J. Mar. Biosci. Biotechnol. 2018, 10, 62-72. 